PROF. MICHELE ACUTO (Orcid ID : 0000-0003-4320-0531)

Article type : Special Section Article

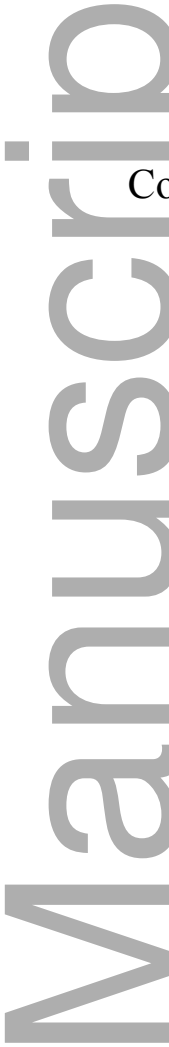

\title{
C40 Cities inside out
}

\author{
Michele Acuto \\ ${ }^{*}$ Connected Cities Lab, University of Melbourne \\ Mehrnaz Ghojeh \\ Special Projects, C40 Cities Climate Leadership Group \\ A response to 'A Decade of $\mathrm{C} 40$ : Research Insights and \\ Agendas for City Networks', \\ Kathryn Davidson, Lars Coenen, Brendan Gleeson ${ }^{1}$
}

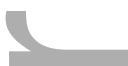

The C40 Climate Leadership Group has repeatedly captured business interest, media reporting and public limelight when it comes to putting cities on the stage, quite literally, on major environmental challenges. The essay by Davidson, Coenen and Gleeson captures this zeitgeist and arrives in a very timely manner as C40 prepares for its 2019 Mayors Summit and fifteenth anniversary in 2020.

In the spirit of offering a "friendly rejoinder and a modest amendment" to Davidson et al., as suggested by Gordon and Johnson in this special section, we offer an 'inside out' view of what C40 represents in the current landscape of global policy and a stock take of their work is much needed.

\footnotetext{
${ }^{1}$ Davidson, K., Coenen, L., and Gleeson, B. (2019), A Decade of C40: Research Insights and Agendas for City Networks, Global Policy, 11 (4), doi: 10.1111/1758-5899.12740

This is the author manuscript accepted for publication and has undergone full peer review but has not been through the copyediting, typesetting, pagination and proofreading process, which may lead to differences between this version and the Version of Record. Please cite this article as doi: $10.1111 / 1758-5899.12760$
}

This article is protected by copyright. All rights reserved 
This means, acknowledging more explicitly how networks like C40, or international urban policy programmes more generally, are situated within a broader political economy of 'global urban governance' (Acuto 2018a). It also means unpacking the often convenient use of popular names like 'C40' and 'Arup' to remember that these entities are complex organisational arrangements with internal (within their own organisation) as much as transversal (across them and other similar organisations) politics and, not least, often highly mobile people shaping the ways they act and react internationally.

City networks like $\mathrm{C} 40$ are also not static and finite; rather they tend to benefit from having an agile platform of management and operation, helping them navigate through the complex governance and technical landscape of cities and global policy. Centrally, it is key to preface this by highlighting how C40's organisation and operations have changed substantially over the past 14 years. This has not just been a growth in funding and membership. It has moved, for example, from what was until fairly recently mainly peer-peer match-making activities to increasingly direct technical assistance (i.e. through the Danish and British government grants).

Some more nuance as to the 'international' that C40 operates in is needed. For instance, whilst often grouped together as in the case of 'theme l' in Davidson et al., networks like UCLG, ICLEI and C40 display significant differences. ICLEI and UCLG rely much more explicitly than C40 on a variety of committees and assemblies for their governance and are perhaps more representative of the average city network 'out there' in terms of budget, operations, membership size and overall set up than C40 might be. For instance, UCLG, purportedly the largest organisation of sub-national governments in the world, with over 240,000 members, involves a complex organisational structure of regional chapters and specific 'sections' like Metropolis - a network in itself with 139 members. Equally, environmentally-focused networks are but $29 \%$ of a broader populace where there might be more than 300 networks in operation (Acuto 2016). We must strive not to generalise, but rather contextualise, the lessons of $\mathrm{C} 40$ in a world where the likes of health, with 30 years of city networking experience in WHO alone, or culture, with UNESCO Creative Cities also celebrating its fifteenth anniversary, also operate in a similar space.

A sense of the political economy of global urban governance is key here. Quite rightly, Davidson et al. note how the platform provided by $\mathrm{C} 40$ is "deeply intertwined with major international business and philanthropic actors". In doing so Davidson et al. are rightly echoing concerns on the downsides of 'philanthro-capitalism' (McGoey 2012) that has abruptly come to the fore in city networking following the Rockefeller Foundation's decision not to continue its support of the $\$ 200 \mathrm{~m}$ initiative 100 Resilient Cities. C40 has also relied on similar types of funding through its three strategic funders, Bloomberg Philanthropies, Danish Realdania, Children Investment Fund Foundation (CIFF) and, previously, Clinton Foundation. In recent years, however, $\mathrm{C} 40$ has aimed at a strategic funding diversification and has attracted other major donors (as the recent UK Government's $£ 27.5 \mathrm{~m}$ grant) and increasingly a wider typology of donors like L'Oréal, GIZ, and EAT. In doing so C40 ushered in the early 2000s a 
different way of networking cities that has perhaps diverged from, but also impacted the thinking of, the likes of ICLEI and UCLG, whilst it also needs to co-exist with these more traditional forms of organisation, with a particular eye at a composite funding base.

This view also helps us understand cities and city networks are not always on the 'doorstep' of and "pushing and prodding" on states, but rather intertwined in a more complex political economy that is still heavily dependent on national governments. C40 has received important support from the UK, German and Danish governments, engaged regularly with multilateral (e.g. World Bank and InterAmerican Development Bank) and UN actors, and played an important role in enhancing to some degree the international affairs literacy of the everyday operate of municipal governments.

A sense of $\mathrm{C} 40$ in context also acts as a reminder that climate and environmental actions are but a piece of a larger puzzle. C40 has also picked up ICLEl's original emphasis on monitoring and made it into a foundational credo of what might in practice be a new global paradigm of data-driven city policymaking. C40's efforts at mobilising information and data about climate action are tightly intertwined with international consultancies, with a prominent role of the Carbon Disclosure Project (CDP) and of ARUP in its major reports. This dimension has become central, others have argued (Lee and Jung 2018), to justify the continued value of city networks. Understanding that this approach is mirrored, espoused and reinforced by the broader political economy of global urban governance, with international agendas like the SDGs but also private sector actors like Arup, promoting it, is once again key. Acknowledging this helps us, as scholars and practitioners, to find a possible entry point for today's most pressing urban questions. This for instance offers a critical transnational bridge of expertise exchange and science-policy collaboration (Acuto 2018b) that, as in the case of the 'CitiesIPCC' campaign championed by C40 (Bai 2018), has begun pushing for more thorough evidence-based action at the city level with a clear international (and some cases cosmopolitan) ethos at its core.

Generative experimentation emerges then as a result not just of closed feedback loops within 'circles' like $\mathrm{C} 40$, but a real political economy of urban information spanning continents, sectors and cutting across cities large and small (Smeds and Acuto 2018). On this Davidson et al. are correct but perhaps only spotting the pinnacle of the iceberg of the current information ecosystem shaping the ways cities see themselves 'in a world of cities' - to paraphrase Jenny Robinson's expression (2011). Overemphasising C40 runs the risk to fall in the same "metrocentric" (Bunnell and Maringanti 2010) bias often presented to by C40's 'representativeness' of cities as a whole.

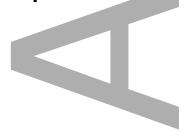

Yet the challenge is also not to take $\mathrm{C} 40$ as a purely unitary entity. In this sense we could speak of multiple 'C40s': there is C40 as the group of mayors, perhaps best concretized by its mayoral chair (Anne Hidalgo from Paris at the time of writing) and mayoral steering committee, standing as the 'voice' of (global) cities as a group of local governments. Yet there is also C40 as the non- 
governmental organisation seeking to connect those cities and make that group 'do' things on an international stage, perhaps best concretized by its secretariat team (mainly based in London at the time of writing) functioning as a fundamental glue to maintain a continuous engagement. The latter can be nuanced even further; there is 'C40 for Mayors' and 'C40 for Cities'. Both are a core part of how $\mathrm{C} 40$ operates and engages in the 'glocal' landscape of urban decision making. The practical and day to day mechanisms through which C40 supports and engages its mayors is often significantly different to that of its cities. C40 for Mayors has typically consisted of a set of advocacy and diplomatic activities often manifested through strategic global platforms and events and more recently through joint declarations; all in what has been an effective attempt to raise the influence and power of cities on the global stage. C40 for Cities and more specifically city officials, typically defined as C40's technical work, is generally less clear-cut and less critically studied; both in terms of what change, support or influence it aims to provide and by whom this is ultimately provided (i.e. C40 team, funder or delivery partner). These more mundane institutional dimensions are often so crucial and lost to the visibility of the frontrunners of these networks and of the 'urban age' rhetoric more in general. Yet the richness of what goes on behind the scenes is often highly explanatory of the place of $\mathrm{C} 40$ and other networks in the geography of global urban governance.

This 'inside' view reminds us of the unevenness of global urban governance actors and institutions. Secretariats and governance structures of networks and, more widely, international urban policy initiatives in private, multilateral and even community sectors (like those at the World Economic Forum, UNESCO or Asian Coalition for Housing Rights, to name but a few) vary substantially in set up, resources and operations. It also underscores an increasingly wide realm of professional 'urban' experts that often escapes traditional job descriptions, part local government officer, part NGO campaigner, part private sector entrepreneur and part diplomat. These global urban 'brokers' and city networkers are central to many of the stories, conclusions and shortcomings of the academic readings of $\mathrm{C} 40$ and yet are often invisible in these narrations. Perhaps we could do better at recounting the role of individuals in this burgeoning 'business' of city networking. This is an inside out agenda that calls for a better understanding of 1) the internal governance and broader politicaleconomy of networks, 2) the role of global urban brokers and experts in networks specifically but also international urban policy (making) more generally, 3) the key trends in (various form of) financial support for and tangible impact of city networks and 4) the role of individuals and 'talent' mobility in this global urban governance space.

From both outside and inside views, then, it might be that 'networked urbanism' is in fact not so much "disruptive" as Davidson et al. (and Davidson \& Gleeson 2018) put it, as centrally constitutive of the contemporary dominant forms of urban management. This is something that, perhaps a little too critically but still effectively, Davidson and Gleeson (2015; and Heikkinen et al. 2019) had already flagged a few years back. Networked urbanism à la C40 might be representative of key trends shaping the direction of global (urban) governance (Curtis 2016). It might also be constitutive of a shift in the foundations of political economy, and a pivotal role of cities in the contemporary transformation of what counts as politics, which few have acknowledged explicitly to date (Curtis 2018). 
Nonetheless, Davidson, Coenen and Gleeson do us a great service here: they have opened up once again the black box of city networking, done so on the basis of a scholarly evidence-driven conversation, and allowed an open forum for academics (of all career paths) and practitioners to debate the challenges and merits of $\mathrm{C} 40$ - an approach we can only hope will be contagious across the variety of challenges affecting global policy today.

\section{References}

Acuto, M. (2013). The new climate leaders? Review of International Studies, 39(4), 835-857.

Acuto, M. (2016). Give cities a seat at the top table. Nature, 537(7622), 611-13.

Acuto, M. (2018a). Engaging with global urban governance. In Harrison, J., \& Hoyler, M. (Eds.). (2018). Doing global urban research. Sage, pp. 96-109.

Acuto, M. (2018b). Global science for city policy. Science, 359(6372), 165-166.

Bai, X., R. J. Dawson, D. Ürge-Vorsatz, G. C. Delgado, Barau A. Salisu, S. Dhakal, D. Dodman, Leonardsen, L., Masson-Delmotte, V., Roberts, D.C. and Schultz, S. "Six research priorities for cities and climate change." Nature 555, no. 7694 (2018): 23.

Bouteligier, S. (2012). Cities, networks, and global environmental governance: spaces of innovation, places of leadership. Routledge.

Bunnell, T., \& Maringanti, A. (2010). Practising urban and regional research beyond metrocentricity. International Journal of Urban and Regional Research, 34(2), 415-420.

Curtis, S. (2016). Cities and global governance: State failure or a new global order? Millennium, 44(3), $455-477$

Curtis, S. (2018). Global cities and the ends of globalism. New Global Studies, 12(1), 75-90.

Davidson, K., \& Gleeson, B. (2015). Interrogating urban climate leadership: Toward a political ecology of the C40 network. Global Environmental Politics, 15(4), 21-38.

Gordon, D. J. (2013). Between local innovation and global impact: cities, networks, and the governance of climate change. Canadian Foreign Policy Journal, 19(3), 288-307.

Heikkinen, M., Ylä-Anttila, T., \& Juhola, S. (2019). Incremental, reformistic or transformational: what kind of change do $\mathrm{C} 40$ cities advocate to deal with climate change? Journal of Environmental Policy \& Planning, 21(1), 90-103.

Lee, T., \& Jung, H. Y. (2018). Mapping city-to-city networks for climate change action: Geographic bases, link modalities, functions, and activity. Journal of cleaner production, 182, 96-104.

McGoey, L. (2012). Philanthrocapitalism and its critics. Poetics, 40(2), 185-199.

Robinson, J. (2011). Cities in a world of cities: the comparative gesture. International journal of urban and regional research, 35(1), 1-23.

Smeds, E., \& Acuto, M. (2018). Networking cities after Paris: Weighing the ambition of urban climate change experimentation. Global Policy, 9(4), 549-559. 
Michele Acuto is Professor of Global Urban Politics and Director of the Connected Cities Lab at the University of Melbourne. He is also a Senior Fellow of the Chicago Council on Global Affairs and of the Robert Bosch Foundation Global Governance Futures program.

Mehrnaz Ghojeh is Manager of Special Projects at C40 and co-founder of UE:EU. She serves as Senior Urban Advisor to mayors and city officials globally. Her research focuses on the evolving role of city networks and the governance challenges facing planetary health.

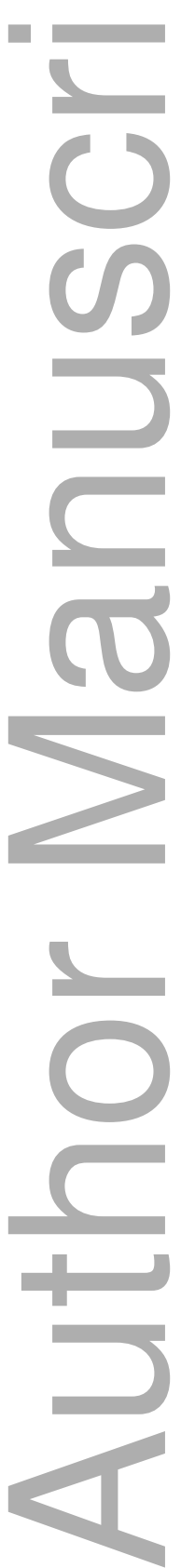

This article is protected by copyright. All rights reserved 


\section{University Library}

\section{- M M I E R R VA A gateway to Melbourne's research publications}

Minerva Access is the Institutional Repository of The University of Melbourne

Author/s:

Acuto, M;Ghojeh, M

Title:

C40 Cities Inside Out

Date:

2019

Citation:

Acuto, M. \& Ghojeh, M. (2019). C40 Cities Inside Out. Global Policy, 10 (4), pp.709-711. https://doi.org/10.1111/1758-5899.12760.

Persistent Link:

http://hdl.handle.net/11343/286814 